\title{
Accounting
}

\section{Green accounting, material flow cost accounting and environmental performance}

\author{
I Gusti Ketut Agung Ulupui ${ }^{a^{*}}$, Yunika Murdayantia ${ }^{a}$ Astari Cita Marinia ${ }^{a}$ Unggul Purwohedi ${ }^{a}$, \\ Mardi $^{\mathrm{a}}$ and Heri Yanto
}

${ }^{a}$ Faculty of Economics, Jakarta State University, Jakarta, Indonesia

${ }^{b}$ Economics Faculty, UNIVERSITAS NEGERI SEMARANG, Indonesia

\begin{tabular}{l}
\hline C H R O N I C L E \\
\hline Article history: \\
Received March 102020 \\
Received in revised format March \\
152020 \\
Accepted June 102020 \\
Available online \\
June 102020 \\
\hline Keywords: \\
Green accounting \\
MFCA \\
Environmental performance \\
PROPER
\end{tabular}
A B S T R A C T

\begin{abstract}
The purpose of this study is to determine the effects of green accounting and Material Flow Cost Accounting (MFCA) on environmental performance as indicated by PROPER rating. This study is conducted on cement manufacturing companies in Indonesia by using a descriptive quantitative research model tested on three variables: green accounting, MFCA, and environmental performance. The green accounting aspect is taken from the extent of Global Reporting Initiative (GRI) disclosure and MFCA is focused on the effectiveness of costs. The MFCA dimensions are production costs, size of production area, and production value. Environmental performance aspect is measured by the PROPER rating issued by the Ministry of Environment and Forestry. The study is conducted in several stages. First, a literature review of previous research related to green accounting, MFCA, and environmental performance is performed. Next, the research problems are formulated. After that, the data from the companies are collected and analyzed by using SmartPLS. Finally, it is concluded that green accounting affects environmental performance, whereas MFCA has no effect on environmental performance.
\end{abstract}

\section{Introduction}

Currently, issues related to infrastructural development have been hot topics for discussion in Indonesia (Ma'ruf \& Daud, 2013; Sukma, 2015). Indonesian government's efforts to develop infrastructures are expected to contribute to the country's economic growth. Despite all the polemics and skeptical views of the infrastructural development, the government is determined to complete the ambitious work program which has already been designed, and they are willing to spend an enormous budget of more than Rp4,000 trillion. This is because they think that the development of infrastructures has become an urgent necessity, particularly for a country as big as Indonesia. Moreover, many Indonesian people have been expecting these long-awaited projects, such as Trans-Java toll road, Trans-Papua Highway, MRT, and LRT. The obvious effect of this massive infrastructural development is an increase in the market needs. However, the increase in the development must be balanced with the conservation of natural resources of local environment to ensure their preservation and sustainable availability (Dascalu et al., 2010; Kates et al., 2005; Lynch, 2011; Chouhan et al., 2017). Azapagic (2003) proposes a corporate sustainability management system (CSMS) consisting of five stages: policy development, planning, implementation, communication, review of progress

* Corresponding author

E-mail address: igka-ulupui@unj.ac.id (I G. K. A. Ulupui) 
and corrective action (Bare, 2011; Al-Adamat et al., 2020). These five stages are formulated by using four indicators: economic, technological, social, and environmental. One type of industry which is directly involved in infrastructural development projects in Indonesia is the cement industry (Daniel, 2009; Rieckhof et al., 2015).

Cement is one of the main substances used for construction. Naturally, an increase in the infrastructural development may result in the concomitant increase in the demands for cements which compels the cement manufacturers to increase their productivity. In doing so, the manufacturers have to deal with sustainability dimensions: economic, technological, social, and environmental. These dimensions are based on efficiency and effectiveness of production and waste-treatment costs (Darwin, 2007). Furthermore, the manufacturing company is required to develop its sustainability concept which is environmentally friendly in its production processes to a certain extent which enables the integration of the company's needs for productivity and the local community needs for environmental protection. In this respect, environmental performance can have a significant effect on the company's financial position. This also indicates the need for adequate environmental cost information (Hansen \& Mowen, 2007; Hendratno, 2016; Marota et al., 2017; Marota, 2017). The company's environmental preservation program might get a positive perception from the local community. Eventually, this local community will place great trust in the company which may promote an increase in their loyalty to use the company's products, which can increase the company's sales (Hasyim \& Jabid, 2019).

To balance the company's production processes with the demands for environmentally friendly processes, the company needs to apply green accounting. Green accounting can help the company increase the efficiency and effectiveness of its resources sustainably which can be aligned with the company's development of environmental functions and benefit the local community. Other than creating a beneficial environmental sustainability, the company also needs a clear concept of how to ensure the company's own sustainability. According to de Beer \& Friend (2006), one of the factors that can help improve the environmental performance is environmental accounting. Green accounting plays a major role in improving environmental performance which refers to one of the accounting functions: presenting useful information to management.

A number of studies on the role of green accounting have been conducted (Zulhaimi, 2015; Anggraini, 2006; Almilia \& Wijayanto, 2007; Uma \& Bougie, 2013). His research demonstrates how green accounting application can affect the company's performance by studying Green Industry Award-Winning companies listed on the IDX. Zulhaimi's work suggests a conclusion that the application of green accounting is very beneficial for the companies, the consumers and the surrounding environment. The application of green accounting for consumers is marked by an increase in earnings and in stock price growth.

Material Flow Cost Accounting (MFCA) (Christ \& Burritt, 2014, 2017; Doorasamy, 2014; Fakoya, 2014) is a type of management accounting method. In contrast with traditional methods, MFCA takes into account the transparency of material flows and the incurring costs which are related to product and material losses during manufacturing processes which cover all economic resources, from the raw material losses (input) to waste disposal (Hyršlová, Vágner, \& Palásek, 2011). This MFCA concept is beneficial for companies to increase their sustainability, particularly by reducing the impact of waste, minimizing inefficient use of materials and energy, and reducing the company's financial costs. Schaltegger, Bennet, Burritt, \& Jasch (2008) explains that MFCA is an environmental management accounting tool which is able to reduce environmental impacts and costs simultaneously, and its application can result in an efficient environmental performance.

Abdel-Kader (2011) promotes MFCA as a powerful method for environmental performance management, and it has been developed as a tool to increase material productivity in manufacturing operations. Abdel-Kader (2011) continues by claiming that companies must use MFCA because it can help them realize that by increasing the transparency of material losses, they can reduce environmental impacts and increase business efficiency. Moreover, MFCA should be perceived as an extension of conventional process which is based on a detailed mapping of the material and energys flow through an organization (Wagner, 2015). However, there is a necessary condition that the costs of wasted materials (or non-product output) are not absorbed into the costs of the product, but they are identified and reported separately. Abdel-Kader (2011) is in line with Schmidt and Nakajima (2013) who claim that MFCA can improve environmental performance. The method is applied by manufacturing companies to evaluate material losses and to identify possible efficiency of resources and saving costs which can result in a higher profitability.

Scavone (2006) is also of the opinion that MFCA methodology is adequate to increase the efficiency of production systems which can reduce the cost of the actual materials used and the costs in material handling and waste disposal. By doing this, the flow of material becomes more transparent. Jasch (2009) states that MFCA has been used in many countries, including Japan where big companies and regulators have used MFCA in their processes of environmental performance efficiency.

The objective of this present study is to identify the effects of green accounting and MFCA on the environmental performance of cement companies listed on Indonesian Stock Exchange (IDX). This research can bring significant benefits, and the results suggest that companies should apply green accounting and MFCA to experience better environmental performance. 


\section{Theoretical review}

\subsection{Green Accounting}

Green accounting is a subtype of environmental accounting that illustrates the measures taken by a company to combine the environmental and cost benefits as an important information into the company's decision-making processes or as a financial outcome of business. According to EPA, green accounting is the identification, prioritization, quantification or qualification, and incorporation of environmental costs into business decisions (Datta \& Deb, 2012). Green accounting management uses environmental costs and performance data to help making business decisions by collecting data on the costs of production, inventory, waste treatment, and environmental performance. In other words, green accounting management is a combined approach that provides the transition of data from financial accounting and cost accounting to improve material efficiency, reduce environmental impact and risk, and reduce the cost of environmental protection (Le \& Nguyen, 2019).

In short, green accounting concept can be described as the production processes in a company which uses its resources in more efficient and more effective ways to achieve the company's sustainability. The results enable the company's development to be aligned with its environmental function which can also bring more benefits to the local community. In this case, the implementation of green accounting involves the concept of savings, e.g. material saving, land saving, and energy saving. The objective of green accounting implementation is to improve the efficiency of the environmental management by conducting environmental assessment of the company's production activities from the perspective of costs and benefits or effects, all of which is expected to create the environmental protection effects. In brief, the implementation of green accounting can provide information on the extent of measures which have been taken by a company which can bring positive or negative contribution to improve the quality of human life and the surrounding environment.

\subsection{Material Flow Cost Accounting}

Material Flow Cost Accounting (MFCA) is a tool or technique to manage the flow of manufacturing processes including the flow of the waste (undesirable material residues). By using MFCA, SMEs or big companies will be able to calculate and minimize the material losses. Basically, MFCA is a tool to reduce costs by waste reduction which eventually can lead to the improvement of business productivity. According to the Guide for MFCA (Environmental Industries Office (Loen, 2011), a brief procedure for implementing the MFCA is suggested as follows:

\section{a. Preparation}

During the preparation phase, target products, lines, and processes must be clearly identified. Then a rough analysis of the target process and the determination of the quantity centers and the scope of the MFCA study are determined. Finally, the materials used in the target process or product are recorded, and data collection is planned.

\section{b. Data collection and compilation}

In this phase, data collection and the compilation of the material types, the determination of the input and the waste quantities in each process, and the calculation of the data regarding the system costs and the energy (labor) costs are carried out. Then the allocation rules for the system and the energy (labor) costs are also determined.

\section{c. MFCA calculation}

An MFCA calculation model is created, and the collected data are inputted. The costs of positive and negative products can be allocated based on the mass balancing concept. The cost of positive product is the cost which is put into processed product which is released to the next process, whereas the cost of negative product is the cost which is put into the wasted or recycled items. The results from MCFA calculation are confirmed and analyzed to indicate the negative product costs and their causes.

\section{d. Identification of improved or corrected conditions}

Conditions for improvement, including material losses and cost reductions, are identified and listed.

e. Formulating improvement plan

To formulate an improvement plan, an examination of the extents and possibilities of material loss reduction of each alternative must be carried out. After that, the cost-cutting calculation and assessment through material loss reduction (MFCA calculation) are carried out to determine the priorities for improvements and formulate the improvement plans. 
f. Implementation of improvement

The improvement plan is implemented in a real situation. Data collection after the improvement realization must be carried out to evaluate each plan in the next step.

\section{g. Evaluation of the improvement effects}

The identification of the quantities of the inputs and the wasted materials after the completion of the improvement implementation and the MFCA calculation are conducted again to compare the improved process with the previous one. The overall costs and the negative product costs following the improvement are calculated and used in the evaluation of the improvement effects.

\subsection{Environmental Performance}

The environmental performance is the result of the environmental management as an effort to encourage companies to manage the local environment. Indonesian Ministry of Environment and Forestry has taken some measures to encourage companies to engage in the environmental management by implementing the performance rating program which is known as the Program for Pollution Control, Evaluation, and Rating (PROPER) since 1994. PROPER is intended to compel companies to comply with regulations through reputational incentives and disincentive which require the companies to implement cleaner production. Efforts to improve the companies' environmental performance are expected to encourage companies to create their own environmental preservation initiatives which eventually will enable the sustainability of the companies. PROPER assessment uses a five-color rating system which is more communicative and easier to be understood by the public. Each company gets either gold, green, blue, red, or black. Gold means excellent, and black means very poor. The color indicates the company's environmental performance rating. PROPER assessment includes compliance to regulations on water pollution control, air pollution control, B3 waste control, environmental impact assessment (or AMDAL in Indonesia), and marine pollution control. The regulations are mandatory requirements. A company who complies with the minimum standard in the regulations can get a blue rating, whereas a company who does not comply with the minimum standard in the regulations can get a red or even black rating (Nuryanti et al., 2015).

\subsection{The Effects of Green Accounting on Environmental Performance}

The green accounting concept has been expected as a new and better means to improve the preservation of environment because by implementing green accounting a company will voluntarily comply with government regulations and policies in the local areas where the company is operating. According to Schaltegger et al. (2008, p. 240), the most obvious institutional aspect (i.e. from the government) which can coercively impose the regulations to the company and ensure the success of green accounting implementation with regard to economic activities is the regulatory aspect, i.e. regulations and policies of local governments as corporate stakeholders. This is supported by a research by Seetharaman, Ismail, and Saravanan (2007) which states that the integration of green accounting into a complex environmental management system can serve as a self-regulatory compliance to the existing regulations and policies. In line with the other studies mentioned earlier, de Beer and Friend (2006) is able to prove that the disclosure of all environmental costs (internal and external), the cost allocation types, and the detection of the triggers in the structured environmental accounting will contribute to the environmental performance.

$\mathrm{H}_{1}$. The application of green accounting affects the environmental performance.

\subsection{The Effects of MFCA on Environmental Performance}

Schaltegger et al. (2008) and Abdel-Kader research (2011) believe that MFCA is one of EMA tools which can be used by a company to manage environmental performance and reduce the environmental impacts and costs simultaneously which, in turn, can improve the effectiveness of the company's environmental performance. MFCA can be applied by increasing the transparency of material losses which can reduce environmentals impact and increase business efficiency. This present study describes the process by involving the detailed mapping of the material and energy flow through an organization, but the costs of wasted materials (non-product output) are not absorbed into the product costs as they are identified and reported separately. This research believes that MFCA has been developed as a tool to increase material productivity in manufacturing operations. In line with the other studies mentioned earlier, Schmidt et al. $(2013,2014)$ also claim that MFCA has an effect on improving environmental performance. In this present study, MFCA is applied by manufacturing companies to assess material losses through inefficient use of resources and identify possible savings that can result in a higher economic benefit. In addition, Scavone (2006) argues that MFCA is a methodology that is adequate to create better data and improve the efficiency of the production system which leads to lower cost of the actual materials used and lower cost in material handling and waste disposal. 
H2. The application of MFCA affects environmental performance.

\section{Research model}

This study uses the quantitative descriptive approach, and it aims to analyze the effects of green accounting and MFCA on environmental performance of cement manufacturing companies listed in Indonesia Stock Exchange (IDX) from 2013 to 2018. It studies three variables: green accounting, MFCA, and their effects on environmental performance. The green accounting aspect is seen from GRI 4 disclosure, and MFCA aspect is focused on the effectiveness of the companies' costs. The dimensions used in MFCA variable are production costs, production value, and the size of production areas (See Table 1).

Table 1

Green Accounting and MFCA Variables

\begin{tabular}{ccc}
\hline Variable & Data & Measurement \\
\hline Green accounting & GRI Index 4 & GRI Disclosure \\
\hline \multirow{2}{*}{ MFCA } & Production costs & Monetary \\
& Size of production area & Area Unit \\
\hline
\end{tabular}

Environmental performance environment is measured by using the scoring system based on the companies' PROPER rating. The rating score is shown in Table 2.

Table 2

Environmental Performance Data based on PROPER Rating

\begin{tabular}{ccc}
\hline Color & Rating Score & Performance Level \\
\hline Gold & 5 & Excellent \\
Green & 4 & Good \\
Blue & 3 & Adequate \\
Red & 2 & Poor \\
Black & 1 & Very Poor \\
\hline
\end{tabular}

Data source: The Ministry of Environment and Forestry

This study is designed by using a quantitative method with descriptive and inferential analyses. The inferential analysis uses purposive sampling and causality analysis.

$K L=a+b 1 G A+b 2 M F C A$

KL : Environmental Performance GA : Green accounting MFCA : Material Flow Cost Accounting

The research uses secondary data which are obtained by using SmartPLS software to conduct the statistical analysis. The data of the cement manufacturing companies are obtained from the Indonesia Stock Exchange. The green accounting data are obtained from the GRI disclosure issued by the cement companies. The PROPER rating data are taken from the Ministry of Environment and Forestry website. The study uses two tests: the descriptive statistics and the regression test by using SmartPLS. The descriptive statistics is used to get the maximum value, minimum value, average value, and standard deviation of variance. The analyses are intended to find a general description of the data which can help the readers understand this research.

\section{Results and discussion}

The research population is all cement companies listed on IDX from 2013 to 2018. There are 6 cement manufacturing companies. The samples are selected by using judgment sampling (i.e. purposive sampling) with a set of criteria for the selection, one of which is that the selected companies must have PROPER rating. From this PROPER rating criterion, only four companies are eligible: PT Indocement Tunggal Prakarsa Tbk, PT Semen Balfour (Persero), PT Holcim Indonesia Tbk, and PT Semen Indonesia (Persero).

\subsection{Hypothesis Testing Results}

\subsubsection{Outer Model Testing}

The outer model testing which uses SmartPLS must fulfil these criteria: convergent validity, composite reliability and Cronbach's alpha criteria, and collinearity statistics. The convergent validity of the reflexive measurement model on each 
indicator is assessed based on the correlation between the item score and component score estimated with the loading factor value in SmartPLS 3 software. The reflexive size of each indicator is considered high when the correlation is 0.70 higher than the measured constructs or variables. In this research, the limit of factor loading value is set at 0.50 . For the initial stage and the development of the measurement scale, this 0.50 factor loading value is deemed sufficient (Chin, 1998; Ghozali, 2014).

Table 3

Factor Loadings for Measuring MFCA

\begin{tabular}{|c|c|c|c|c|}
\hline \multicolumn{5}{|c|}{ Material Flow Cost Accounting } \\
\hline No. & & Early & Modification 1 & Information \\
\hline 1 & B P & .954 & 1.000 & Valid \\
\hline 2 & LL & -0.319 & & \\
\hline 3 & NP & 0.954 & 1.000 & Valid \\
\hline
\end{tabular}

$\mathrm{BP}=$ production costs

$\mathrm{LL}=$ size of production area

$\mathrm{NP}=$ production value

Table 4

Factor Loadings for Green Accounting Measurement

\begin{tabular}{ccccc}
\hline \multicolumn{3}{c}{ Green accounting } \\
\hline No. & Early & Modification 1 & Information \\
\hline 1 & GA & 1.000 & 1.000 & Valid \\
\hline GA: Green accounting & & &
\end{tabular}

GA: Green accounting

Table 5

Factor Loadings for Environmental Performance Measurement

\begin{tabular}{cccccc}
\hline \multicolumn{3}{c}{ Environmental Performance } \\
\hline No. & Early & Modification 1 & Information & Valid \\
\hline 1 & TOS & 1.000 & 1.000 & & \\
\hline KL: Environmental performance & & &
\end{tabular}

Based on the results of the outer model testing as seen in Table 3-5, the correlation of each indicator with the variable does not meet the convergent validity because its initial factor loading value is still below 0.50 . The next step is to make a modification by removing the indicator with the lowest factor loading value. Thus, the results of the outer model are obtained as follows. MFCA variable has 3 initial indicators: production costs (BP), size of production area (LL), and production value (NP). A modification needs to be done by eliminating size of production area (LL) because it has a factor loading of -0.319 which is $<$ 0.50. This means the AVE on the LL variable is below 0.50 . Requirements that must be met in this test are as follows:

1) Cronbach's Alpha $>0.7$

2) Rho_A $>0.7$

3) Composite Reliability $>0.6$

4) $\mathrm{AVE}>0.5$

Table 6

Construct Reliability and Validity

\begin{tabular}{ccccc}
\hline & Cronbach's Alpha & rho A & Composite Reliability & Average Variance \\
\hline MFCA & 1.000 & 1.000 & 1.000 & 1.000 \\
GA & 1.000 & 1.000 & 1.000 & 1.000 \\
TOS & 1.000 & 1.000 & 1.000 & 1.000 \\
\hline
\end{tabular}

MFCA : Material Flow Cost Accounting

GA : : Green accounting

KL : Environmental performance

Based on Table 6, the following explanation of each variable can be presented. After passing the construct reliability and validity test, MFCA variable gets a Cronbach's alpha value of 1.000 which is $>0.70$. The rho_a value of 1.000 is obtained which is greater than 0.70 . This means it demonstrates composite reliability value of 1.000 which is greater than 0.60 . and the value of AVE is obtained at 1.000 which is greater than 0.50. Then MFCA variable can be declared as valid and reliable (i.e. which is in line with the conditions in the field). Green accounting variable is tested for the construct reliability and validity, and the results show that it gets a Cronbach's alpha value of 1.000 which is greater than 0.70 . This variable also obtained a rho_a value of 1.000 which is greater than 0.70 . Its composite reliability value is also at 1.000 which is greater than 0.60 , and the value of 
AVE is 1.000 which is greater than 0.50 . This means the green accounting variable can be declared as valid and reliable, which is in line with the conditions in the field. Finally, the environmental performance variable which is also tested for the construct reliability and validity gets a Cronbach's alpha value of 1.000 which is greater than 0.70 . Its rho_a value is obtained at 1.000 which is greater than 0.70 . The composite reliability value is at 1.000 which is greater than 0.60 , and the value of AVE is 1.000 which is greater than 0.50 . Then the environmental performance variable can be declared as valid and reliable, and it is in line with the conditions in the field. From the results, it can be concluded that all constructs have met the validity and reliability criteria. This is indicated by the values of Cronbach's alpha, rho_a, composite reliability, and AVE which have met the criteria.

\subsubsection{Inner Model Testing}

The inner model testing is conducted to determine the relationship between the constructs or between the variables, the value of the significance, and the value of R-squared $\left(\mathrm{R}^{2}\right)$ of the research model. First, the coefficient of determination or R-squared is used to assess the PLS model on each dependent variable. In this study, there is only one dependent variable (i.e. enviromental performance) which is influenced by two independent variables.

\section{Table 7}

Adjusted R-squared

Environmental Performance (KL)

Adjusted R-squared

Table 7 shows that the R-squared value for the dependent variable (environmental performance) which is influenced by MFCA and green accounting variables is at 0.691 or $69.1 \%$, and the rest is explained by other variables.

Second, F-squared analysis is also used. According to Juliandi, Irfan, Manurung, and Satriawan (2018), the Fsquared criteria are as follows,

1) $F^{2}=0.02$ means that the exogenous variable (x) has a small effect on the endogenous variable (y).

2) $\mathrm{F}^{2}=0.15$ means that the exogenous variable $(\mathrm{x})$ has a medium or moderate effect on the endogenous variable (y).

3) $\mathrm{F}^{2}=0.35$ means that the exogenous variable $(\mathrm{x})$ has a large effect on the endogenous variable (y).

Table 8

F-squared value

\begin{tabular}{lr}
\hline MFCA & Environmental Perf \\
Green accounting & 2.236 \\
\hline
\end{tabular}

Based on Table 8, the effect of MFCA on the environmental performance gets an F-squared value of 2.236. This is considered as large according to the criteria. Meanwhile, the effect of green accounting on the environmental performance gets an F-squared value of 0.148 which is considered as small. This mean MFCA has a large effect on environmental performance, whereas green accounting has a small effect on environmental performance. Third, the testing also measures the direct effect by using path coefficients which is used to determine the magnitude of the relationship or influence between the research variables. The estimated value for the path coefficients in the structural model with a significance value of 0.05 . This significance value is obtained by bootstrapping procedure with T-table of 2.07961 . This value is used as a basis for the hypothesis testing.

Table 9

Direct Effect

\begin{tabular}{lccccc}
\hline & $\begin{array}{c}\text { Original } \\
\text { Sample }(\mathrm{O})\end{array}$ & $\begin{array}{c}\text { Sample } \\
\text { Mean (M) }\end{array}$ & $\begin{array}{c}\text { Standard } \\
\text { Deviation } \\
(\text { STDEV })\end{array}$ & $\begin{array}{c}\text { T Statistics } \\
(|\mathrm{O} / \mathrm{STDEV}|)\end{array}$ & P Values \\
$\mathrm{MFCA} \rightarrow \mathrm{KL}$ & -0.247 & -0.243 & 0.129 & 1.920 & 0.055 \\
$\mathrm{GA} \rightarrow \mathrm{KL}$ & 0.962 & .955 & 0.076 & 12.604 & 0.000 \\
\hline
\end{tabular}

In PLS, the statistical testing of every relationship which has been hypothesized is carried out by using simulations. This is done by using the bootstrapping procedure on the samples. The bootstrapping testing is also aimed at minimizing the abnormality problems with the research data. The result of the bootstrapping testing is briefly elaborated for MFCA and green accounting variables. First, based on the test results in Table 9, MFCA's effect on environmental performance has a coefficient value of 0.247 (negative value). This means MFCA has a negative relationship with environmental performance although it is not 
significant. The t-statistics is obtained at 1.920 which smaller than the t-table of 2.07961 , and the p-value is obtained at 0.055 which is greater than the significance value of 0.05 . This result shows that MFCA has negative relationship with environmental performance, but it is not significant. Thus, the first hypothesis cannot be accepted because MFCA does not affect environmental performance. Second, green accounting's effect on environmental performance receives a coefficient value of 0.962 (positive value) which means that green accounting has a positive relationship with environmental performance. The t-statistics is obtained at 12.604 which is greater than the t-table at 2.07961, and the p-value is obtained at 0 which is greater than the significance value of 0.05 . The results shows that green accounting has a positive and significant relationship with environmental performance. Thus, the second hypothesis can be accepted. Green accounting affects environmental performance.

\section{Discussion}

Based on the analysis above, the second hypothesis is accepted. This means green accounting is proven to have an effect on environmental performance. The application of green accounting is expected to improve the preservation of the environment because the companies which implement green accounting are voluntarily comply with government regulations and policies in the area where the companies are operating. According to Schaltegger et al. (2008, p. 240), two factors which can ensure the success of green accounting implementation with regard to economic benefits is the regulations and policies imposed by the local governments as one of the corporate stakeholders. Seetharaman et al. (2007) confirm this by stating that the integration of green accounting into the environmental management system can serve as a self-regulatory compliance to the existing regulations and policies. In line with the other studies mentioned earlier, de Beer and Friend (2006) is able to prove that the disclosure of all environmental costs (internal and external), the cost allocation types, and the detection of the triggers in the structured environmental accounting will contribute to the environmental performance.

\section{Conclusion}

This study discusses the effects of green accounting and MFCA on environmental performance. The results suggest that the implementation of green accounting affects environmental performance. On the contrary, MFCA has no influence on environmental performance.

\section{References}

Abdel-Kader, M. G. (Ed.). (2011). Review of management accounting research. New York: Palgrave Macmillan.

Al-Adamat, A., Al-Gasawneh, J., \& Al-Adamat, O. (2020). The impact of moral intelligence on green purchase intention. Management Science Letters, 10(9), 2063-2070.

Almilia, L. S., \& Wijayanto, D. (2007). Pengaruh environmental performance dan environmental disclosure terhadap economic performance. Proceedings of the 1st Accounting Conference, Depok, 1, 7-9.

Anggraini, Fr. R. R. (2006, August). Pengungkapan informasi sosial dan faktor-faktor yang mempengaruhi pengungkapan informasi sosial dalam laporan keuangan tahunan: Studi empiris pada perusahaan-perusahaan yang terdaftar di Bursa Efek Jakarta. Paper presented at Simposium Nasional Akuntansi 9, Padang. http://dx.doi.org/10.1016/j.jclepro.20 14.10.039.

Azapagic, A. (2003). Systems approach to corporate sustainability: A general management framework. Trans IChemE Journal, 81(B), 303-316.

Bare, J. C. (2011). Five key elements for environmental sustainable progress. International Journal for Sustainable Innovations, 1(1), 91-98.

Chin, W. W. (1998). The partial least squares approach to structural equation modeling. In Marcoulides, G. A. (Ed.), Modern methods for business research (pp. 295-336). London: Lawrence Erlbaum.

Christ, K. L., \& Burritt, R. L. (2014). Material flow cost accounting: A review and agenda for future research. Journal of Cleaner Production, 108, 1378-1389.

Christ, K. L., \& Burritt, R. (2017). Material flow cost accounting for food waste in the restaurant industry. British Food Journal, 119(3), 600-612. https://doi.org/10.1108/BFJ-07-2016- 0318.

Chouhan, V., Soral, G., \& Chandra, B. (2017). Activity based costing model for inventory valuation. Management Science Letters, 7(3), 135-144.

Daniel, A. (2009). Environmental and material flow cost accounting [Review of the book Environmental and Material Flow Cost Accounting: Principles and Procedures]. Issues in Social and Environmental Accounting, 3(1), 95-97.

Darwin, A. (2007). Pentingnya laporan keberlanjutan. Akuntan Indonesia, 3(1), 12-14.

Dascalu, C., Caraiani, C., Lungu, C. I., Colceag, F., \& Guse, G. R. (2010). The externalities in social environmental accounting. International Journal of Accounting and Information Management, 18(1), 19-30.

Datta, R., \& Deb, S. K. (2012). Green accounting: What? Why? Where we are now and where we are heading - A Closer Look. European Journal of Business and Management, 4(4), 99-109. 
De Beer, P., \& Friend, F. (2006). Environmental accounting: A management tool for enhancing corporate environmental and economic performance. Ecological Economics, 58(3), 548-560.

Doorasamy, M. (2014). The effectiveness of material flow cost accounting (MFCA) in identifying non-product output costs and its impacts on environmental performance in paper manufacturing companies: A case study in Kwa-Zulu Natal. The Journal of Accounting and Management, 4(3), 51-69.

Fakoya, M. B. (2014). An adjusted material flow cost accounting framework for process waste-reduction decisions in the South African brewery industry. (Dissertation, University of South Africa, 2014). Retrieved from http://uir.unisa.ac.za/bitstream/handle/10500/13942/thesis fakoya mb.pdf?sequence=1.

Ghozali, I. (2014). Structural equal modeling: Metode alternatif dengan partial least square (PLS). Semarang: Badan Penerbit Universitas Diponegoro.

Hasyim, A., \& Jabid, A. (2019). Does cost accounting system contributes in supply chain operations?. Uncertain Supply Chain Management, 7(2), 157-168.

Hansen, D. R., \& Mowen, M. M. (2007). Managerial accounting ( $8^{\text {th }}$ ed.). Mason: Thomson.

Hendratno, S. P. (2016). Corporate point of view in green accounting. Binus Business Review, 7(3), $247-253$.

Hyršlová, J., Vágner, M., \& Palásek, J. (2011). Material flow cost accounting (MFCA): Tool for the optimization of corporate production processes. Business, Management and Education Journal, 9(1), 5-18. https://doi.org/10.3846/bme.2011.01.

Jasch, C. M. (2009). Environmental and material flow cost accounting: Principles and procedures. Netherland: Springer.

Juliandi, A., Irfan, I., Manurung, S., \& Satriawan, B. (2018). Mengolah data penelitian bisnis dengan SPSS. Medan: LPPI Aqli.

Kates, R. W., Parris, T. M., \& Leiserowitz, A. A. (2005). What is sustainable development? Goals, indicators, values, and practice. Environment: Science and Policy for Sustainable Development, 47(3), 8-21.

Le, T., \& Nguyen, T. (2019). Practice environmental cost management accounting: The case of Vietnamese brick production companies. Management Science Letters, 9(1), 105-120.

Loen, M. (2018). Penerapan green accounting dan material flow cost accounting (MFCA) terhadap sustainable development. Jurnal Akuntansi \& Bisnis Krisnadwipayana, 5(1), 1-13.

Lynch, K. D. (2011). Measuring corporate sustainability performance: Influences and issues to consider in metric conceptualization. (Doctoral dissertation, Benedictine University, 2011). Retrieved from ProQuest, UMI Dissertations Publishing, 3471627.

Marota, R., Marimin, M., \& Sasongko, H. (2015). Perancangan dan penerapan material flow cost accounting untuk peningkatan keberlanjutan perusahaan PT XYZ. Jurnal Manajemen dan Agribisnis, 12(2), 92-105.

Marota, R. (2017). Green concepts and material flow cost accounting application for company sustainability. Indonesian Journal of Business and Entrepreneurship, 3(1), 43-51.

Ma'ruf, Y. P., \& Daud, J. (2013). Pengaruh investasi infrastruktur jalan terhadap pertumbuhan ekonomi wilayah di kabupaten Pesisir Selatan provinsi Sumatera Barat. Jurnal Teknik Sipil USU, 2(3), 1-12.

Ministry of Economy, Trade and Industry (METI). (2010). Environmental Management Accounting: MFCA Case Examples. METI: Tokyo.

Nakajima, M., Kimura, A., \& Wagner, B. (2014). Introduction of material flow cost accounting (MFCA) to the supply chain: A questionnaire study on the challenges of constructing a low-carbon supply chain to promote resource efficiency. Journal of Cleaner Production, 108, 1302-1309.

Nuryanti, T. N., Nurlely, N., \& Rosdiana, Y. (2015). Pengaruh akuntansi lingkungan terhadap kinerja lingkungan: Pada perusahaan tekstil wilayah Bandung. Prosiding Akuntansi-SPeSia, 1(1), 214-220.

Rieckhof, R., Bergmann, A., \& Guenther, E. (2015). Interrelating material flow cost accounting with management control systems to introduce resource efficiency into strategy. Journal of Cleaner Production, 108(B), $1262-1278$.

Scavone, G. M. (2006). Challenges in internal environmental management reporting in Argentina. Journal of Cleaner Production, 14, 1276-1285. Retrieved from http://www. Sciencedirect.com.

Schaltegger, S., Bennet, M., Burritt, R. L., \& Jasch, C. M. (Eds.). (2008). Environmental management accounting for cleaner production. Netherland: Springer.

Schaltegger, S., \& Zvezdov, D. (2015). Expanding material flow cost accounting: Framework, review, and potentials. Journal of Cleaner Production, 108, 1333-1341.

Schmidt, A., Götze, U., \& Sygulla, R. (2014). Extending the scope of material flow cost accounting: Methodical refinements and use cases. Journal of Cleaner Production, 108, 1320-1332.

Schmidt, A., Hache, B., Herold, F., \& Götze, U. (2013). Material flow cost accounting with Umberto ${ }^{\circledR}$. Proceedings of the $1^{\text {st }}$ and $2^{\text {nd }}$ workshop of the cross-sectional group 1 "Energy related technology and economic evaluation" of the Cluster of Excellence eniProd, Wissenschaftiche Scripten, Auerbach, 231-247.

Schmidt, M., \& Nakajima, M. (2013). Material flow cost accounting as an approach to improve resource efficiency in manufacturing companies. Resources, 2(2), 358-369.

Seetharaman, A., Ismail, M., \& Saravanan, A. S. (2007). Environmental accounting as a tool for environmental management systems. Journal of Applied Sciences and Environmental Management, 11(2), 137-145.

Sukma, A. F. (2015). Efek pengganda infrastruktur pekerjaan umum dalam perekonomian provinsi Bali. Jurnal Perencanaan Wilayah dan Kota, 26(2), 100-110. 
752

Uma, S., \& Bougie, R. (2013). Research methods for business: A skill-building approach (6 ${ }^{\text {th }}$ ed.). Chichester: Wiley.

Wagner, B. (2015). A report on the origins of Material Flow Cost Accounting (MFCA) research activities. Journal of Cleaner Production, 108, 1255-1261.

Zulhaimi, H. (2015). Pengaruh penerapan green accounting terhadap kinerja perusahaan: Studi pada perusahaan peraih penghargaan industri hijau yang listing di BEI. Jurnal Riset Akuntansi dan Keuangan, 3(1), $603-616$.

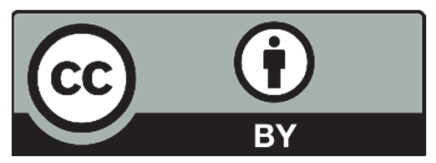

(C) 2020 by the authors; licensee Growing Science, Canada. This is an open access article distributed under the terms and conditions of the Creative Commons Attribution (CC-BY) license (http://creativecommons.org/licenses/by/4.0/). 